2013

\title{
Bivalve Molluscs: Barometers of Climate Change in Arctic Marine Systems
}

\author{
Roger Mann \\ Virginia Institute of Marine Science \\ Daphne M. Munroe \\ Eric N. Powell \\ Eileen E. Hoffmann \\ John M. Klinck
}

Follow this and additional works at: https://scholarworks.wm.edu/vimsbooks

Part of the Aquaculture and Fisheries Commons, and the Marine Biology Commons

\section{Recommended Citation}

Mann, Roger; Munroe, Daphne M.; Powell, Eric N.; Hoffmann, Eileen E.; and Klinck, John M., "Bivalve Molluscs: Barometers of Climate Change in Arctic Marine Systems" (2013). VIMS Books and Book Chapters. 11.

https://scholarworks.wm.edu/vimsbooks/11 


\title{
Bivalve Molluscs: Barometers of Climate Change in Arctic Marine Systems
}

\section{Roger Mann}

The College of William and Mary, Virginia Institute of Marine Sciences, Gloucester Point, Virginia, USA

\section{Daphne M. Munroe}

Rutgers University, Haskin Shellfish Research

Laboratory, Port Norris, New Jersey, USA

\section{Eric N. Powell \\ University of Southern Mississippi, Gulf Coast Research Laboratory, Ocean Springs, Mississippi, USA}

\author{
Eileen E. Hofmann and John M. Klinck \\ Old Dominion University, Center for Coastal Physical \\ Oceanography, Department of Ocean, Earth and \\ Atmospheric Sciences, Norfolk, Virginia, USA
}

\section{Abstract}

Bivalve molluscs store a complete history of their life in the growth lines in their valves. Through sclerochronology, in combination with isotope signatures, it is possible to reconstruct both post-recruitment growth history at the individual level and commensurate environmental records of temperature and salinity. Growth patterns are integrators of local primary productivity; spatial and temporal changes in growth illustrate commensurate patterns of food availability. Mactrid clams are long-lived, benthic dominant species found on inner continental shelves throughout the Northern Hemisphere where they variously support major fisheries (Spisula solidissima in the Mid-Atlantic Bight, Mactromeris polynyma in eastern Canada, Spisula sachalinensis in Japan) and recreational fisheries (Mactromeris polynyma in Alaska), and serve as dietary items for charismatic species such as bearded 
seals (Erignathus barbatus) and walrus (Odobenus rosmarus divergens). Ongoing studies, employing sophisticated adult growth and larval dispersal models of the response of Spisula solidissima to climate change in the Mid-Atlantic Bight, suggest the general use of mactrids as barometers of climate change over broader geographic footprints. Mactromeris polynyma is a candidate species for shallow arctic marine systems, having a pan-arctic distribution from the Gulf of Maine in the Atlantic to the Bering Sea and Gulf of Alaska in the northern Pacific. The longevity of extant individuals ( $\leq 25$ years) provides opportunity for detailed reconstruction of the benthic environment and food regimes at the decadal level.

\section{Introduction}

Climate change is arguably the greatest challenge facing human society today. The Nobel Prize winning report of the Intergovernmental Panel on Climate Change (IPCC 2007) provides a comprehensive overview of the factors contributing to and prospects for continuing climate change. No ecosystem is immune to these changes. Arctic marine ecosystems are suffering the combined impacts of rising temperature, declining seasonal ice cover, and increasing riverine inputs associated with thawing of permafrost. The combination threatens disruption of formerly stable food chains. The potential exists for pelagic primary production to be redirected from benthic to pelagic food chains with resultant impact on apex predators, including some of the most publicly visible and charismatic species of the arctic ecosystem, in addition to broader societal impacts on indigenous communities (e.g., Hunt et al. 2002; Krupnik and Jolly 2002; Duerden 2004; Grebmeier et al. 2006a,b; Burek et al. 2008).

The arctic continental shelves are similar to those of northwest Europe, the middle Atlantic coastline of North America, and much of the northwest rim of the Pacific in having wide and relatively gentle sloping topography with the opportunity (at least seasonally) for windinduced vertical mixing of the water column over enormous areas. At these times surface-generated primary productivity is mixed to the benthos and available for grazing by infauna (Hofmann et al. 2008, $\mathrm{Xu}$ et al. 2011, Munroe et al. 2013). Shelf bathymetry does not preclude benthic production of single cell plankton as diatom mats that offer additional food sources for benthic grazers and infauna (Munroe et al. 2013). Unlike the Antarctic shelf benthos, isolated by a circumpolar current and deep bathymetry, the artic benthos and associated fauna include a large component that is a continuum of boreal species from lower latitudes. The benthos of the shallow arctic seas can thus be characterized as living along an environmental cline from lower latitudes (see for example species distributions in Bernard 1983, Dunton 1992). But the environmental clines are changing, prompting two questions: 
(1) what are the implications of changing primary productivity, both in terms of timing and intensity, in combination with decreased seasonal ice cover on benthic production, and hence water column food chains; and (2) can we use individual based bioenergetic and growth models developed for lower latitude species to inform question (1)? This contribution explores the role that large, long-lived bivalve molluscs offer in responding to the above questions.

\section{Bivalve shells as environmental recorders}

Bivalve molluscs maintain a complete history of their individual life in their shells (valves). The shell structure is a time-based integrator of growth in the seasonally and otherwise oscillating environment that each individual occupies. Shell formation is a process of calcification over a protein matrix effected by the underlying soft tissue mantle, with each layer adding as a laminate to the internal surface of the intact shell (Rhoads and Lutz 1980, Richardson 2001). The carbonate form and crystallography may vary at a species-specific level, as may the presence of an external proteinaceous periostracum. Carbonate dissolution from the internal valve surface can occur during periods of anaerobic respiration to maintain pH balance (Crenshaw and Neff 1969, Wilkes and Crenshaw 1979, Rhoads and Lutz 1980), but this is transitory in terms of longer-term deposition patterns. The overall result is a shell structure inclusive of multiple growth signatures-the challenge is to discriminate the time base and/or the physiological and environmental events that correspond to each signature (review in Richardson 2001; see Schone et al. 2005 and Kilada et al. 2007 for interesting examples).

Growth signatures in individual valves are typically visualized by sectioning from the hinge (dorsal) to the ventral margin and polishing the exposed surface (height of the shell dorsal to ventral). The laminate structure of the individual layers is thus exposed, with each more recent layer being exposed at the growing edge beyond that of the immediate preceding layer. This shingle-like structure results in the concentric growth signatures on the external valve surface. These are subject to erosion over time, thus external signatures are often absent near the hinge region in older individuals, even where an overlaying periostracum may have once been present (for example Arctica island$i c a)$. Even though external signatures may have been lost, the laminate structure of the valve retains the internal signatures and is thus available for reconstruction of the individual life history. Described signatures correspond to annual, spawning, tidal, and disturbance events (Richardson 1988, 2001). At a species-specific level, polished edges of sectioned valves may reveal considerable structure by direct visual examination. The exposed edge can be acid etched and an acetate sheet applied. Upon careful removal, the acetate peel provides a "negative" 
record that can be examined to reveal fine structure with transmission light microscopy (Rhoads and Lutz 1980, Ropes 1984, Richardson 2001). Alternatively, high definition imaging can be used directly on the polished edge (Harding et al. 2008b). Scanning densitometry can be used on images generated by either approach to discriminate growth signatures (Richardson et al. 2005, Harding et al. 2008b). The proverbial "bottom line" is a highly defined chronology of signatures, corresponding to the hinge-to-ventral-margin growth axis, that encompass the entire individual life span and that can be quantified.

Visual signatures are widely used to generate length-at-age relationships, typically by Von Bertalanffy fits (for examples see Sasaki 1981, Jones et al. 1989, Ramón and Richardson 1992). Where species support capture fisheries, the age-at-length curve is a central component, together with mortality estimators from population demographics, size versus fecundity descriptors, and yield estimators (weight at length/ age) in development of sustainable fisheries management plans (for example see Thorarinsdóttir and Jacobsen 2005). Isotope techniques offer resolution to the question of the temporal basis of the sequence of signatures (Jones et al. 1983). Bivalve shells are in situ bathythermographs in that the incorporation of oxygen isotopes into carbonate is temperature and salinity dependent, thus in coastal shelf systems the $\mathrm{O}^{16} / \mathrm{O}^{18}$ ratio provides a now well calibrated record of temperature (Jones and Quitmeyer 1996). The cyclical nature of the ratio identifies seasonal periodicity. The absolute values of the ratio provide environmental temperature proxies from short-term (Kirby et al. 1998, Harding et al. 2010, Chute et al. 2012) to very long-term situations (Schone et al. 2004, 2005). Additionally, cyclical variation in elemental ratios in molluscan shell growth provides tools for investigating seasonal growth (for examples see Richardson et al. 2003 on Pinna nobilis, and Richardson et al. 2005 on the red whelk Neptunea antiqua), while bomb radiocarbon signatures can provide absolute temporal reference points for long-lived species (see Kilada et al. 2009 for application in age verification of the propeller clam, Cyrtodaria siliqua in eastern Canada).

\section{Growth and bioenergetics in bivalves- models overcoming complexity}

Whereas length-at-age relationships enjoy common use in fisheries management, the development of sophisticated bioenergetics models in combination with location-specific length-at-age estimates provide opportunities to examine productivity estimates supporting the observed growth. This is a complex undertaking as the simplified following example illustrates; however, current-modeling efforts can surmount this complexity. Consider the Von Bertalanffy growth function: 


$$
L_{t}=L_{\infty}\left(1-\exp ^{-K(t-t 0)}\right)
$$

where $L_{t}$ is length at time $t$ and $L_{\infty}$ is asymptotic length. The function, generated from length and age data over the increments provided by the previously described sections, allows estimation of the growth constants $(K)$. Length versus biomass relationships (from field samples) can be recast in terms of energy and related to local physical and food environment through manipulations beginning with the energy budget equation. The energy balance in an individual organism is described thus:

$$
C=P+R+F+U
$$

where: $C=$ consumption; $P=$ production, sometimes considered the sum of somatic production $\left(P_{s}\right)$, gonadal production $\left(P_{g}\right)$, and, in the case of molluscs, shell production $\left(P_{s h}\right) ; R=$ respiration (both aerobic and anaerobic); $F=$ fecal production; and $U=$ excretion and secretion. The units are typically in energy per unit time. The equation can be rearranged to estimate $P$ :

$$
P=P_{g}+P_{s}+P_{s h}=C-(R+F+U)
$$

Optimization of the right side of the equation maximizes $P$ and provides an estimation of scope for growth (SFG)-resources in excess of that required for maintenance metabolism (Fig. 1 provides an example). Individual components of the energy budget equation can be related to weight by an allometric relationship (Brown et al. 2004):

$$
\text { Energy }=a W^{b}
$$

where $W$ is a measure of biomass, $a$ is a constant, and $b$ is the exponent describing the size dependency. Values of the constant $a$ generally increase with temperature. Further, the rate is affected by a suite of variables not limited to temperature, such as salinity and oxygen. A simple reflection of this environmental sensitivity can be illustrated as follows:

$$
\text { Energy }=t^{a} W^{b}
$$

where $t$ is a coefficient that has been added to indicate temperature dependence. Consider an example wherein $\mathrm{Q}_{10}$, the increase in physiological rate with a $10^{\circ} \mathrm{C}$ increase in temperature, is different for each of $C, R, F$, and $U$ in the SFG estimator, and the same applies for the constant $a$, and the exponent $b$. So, quantification of SFG requires knowledge of a series of differing allometric relationships with differing $t_{a} a$ and $t_{b} b$ parameters. 


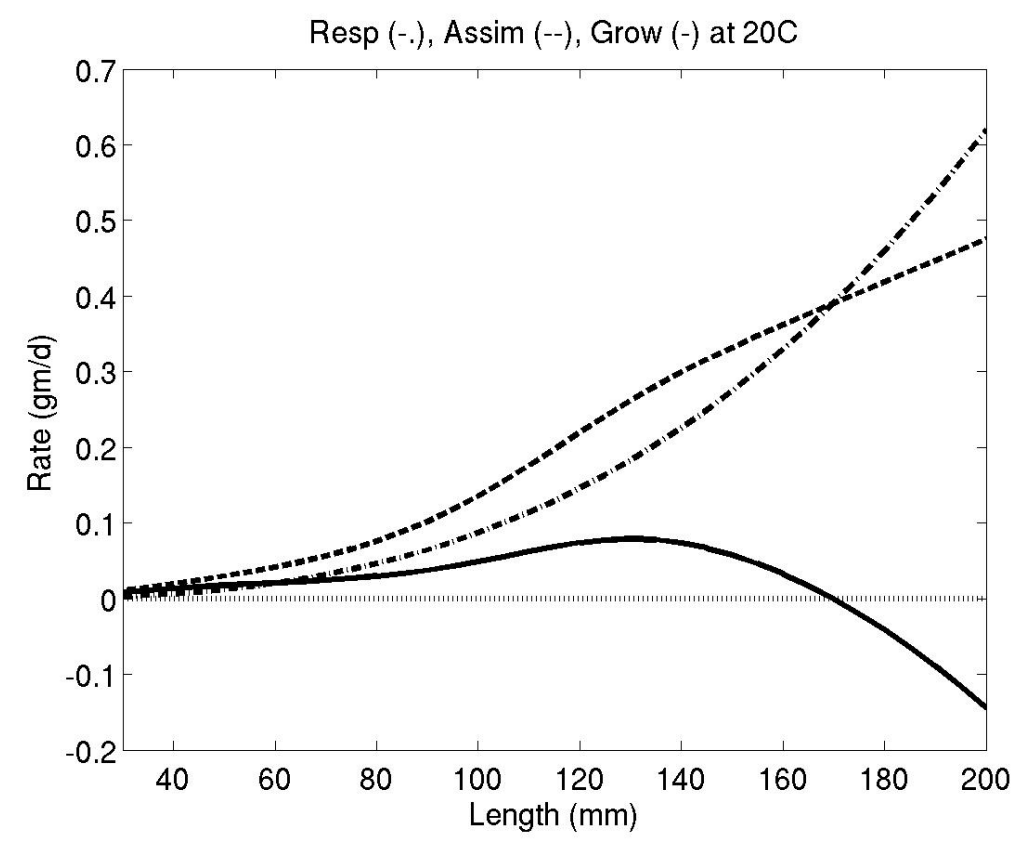

Figure 1. Scope for growth (SFG) of the surfclam Spisula solidissima at $20^{\circ} \mathrm{C}$ and $1 \mathrm{mg}$ per $L$ food. The dissimilarities between the increase in assimilated energy (dotted line) and respiration (dot-dash line) result in gradually increasing SFG to $130 \mathrm{~mm}$ length, after which SFG decreases to zero at about $170 \mathrm{~mm}$. At lengths above $170 \mathrm{~mm}$ SFG is negative under these conditions. Equations for assimilation and respiration are given in Munroe et al. (2013).

In bivalves, consumption (feeding) scales by gill area (square of linear dimension), respiration scales by weight (cube of linear dimension), fecal production scales as for feeding but assimilation may differ with increasing temperature, and excretion depends on, among other things, respiratory substrate, which varies both seasonally and with status of the gametogenic cycle (Bayne 1976; Mann 1978; Mann and Glom 1978; Ren and Ross 2001, 2005; see also Lika and Nisbe 2000). Furthermore the $\mathrm{Q}_{10}$ concept, while useful over limited physiological ranges, does not reflect the nonlinear relationships that exist near thermal minima and maxima. Examples of a complete series of contributing mathematical relationships are described in Munroe et al. (2013) and Hofmann et al. (2006). 
Despite the obvious complexity of the modeling challenge, significant progress has been made since the landmark works in physiological ecology of Bayne and his collaborators on the mussel Mytilus edulis (see Bayne 1976 for an overview). Gross growth efficiency is high for juveniles. But as the animal grows the energy budget is increasingly constrained by the differential increase in ingestion relative to respiration with increasing biomass, as well as the allocation of additional energy to reproduction upon maturity (Calow 1977). Over the past 20 years individual-based models and dynamic energy budget models have been developed based on this principle for oysters, Crassostrea virginica (Powell et al. 1992, 1994, 1995, 1996, 1997; Hofmann et al. 1992, 1994, 1995) and Crassostrea gigas (Kobayashi et al. 1997, Hyun et al. 2001, Ren and Ross 2001); green mussels, Perna canaliculus (Ren and Ross 2005); hard clams, Merceneria mercenaria (Hofmann et al. 2006); Manila clams, Tapes philippinarum (Melia et al. 2004, Flye-Sainte-Marie et al. 2007); and more recently the mactrid surfclam, Spisula solidissima (Munroe et al. 2013). Fig. 2 provides a graphical description of SFG versus temperature for the surfclam Spisula solidissima at a single food concentration.

The contribution of Munroe et al. (2013) in particular is relevant herein because it poses two questions, that is "how much growth can be predicted based on the observed available food?" and the converse "what food resources are required to support the documented growth?," and it does so in an environment where the exact local food conditions of target species are less well understood because of bathymetry. Munroe et al. (2013) conclude that only $65 \%$ of the required food to support observed growth is provided by water column chlorophyll, and that the remainder must be associated with benthic production. Evidence of benthic supplementation of water column food for benthos in comparable bathymetry is rare but not unique (Fry 1988, Hobson et al. 1995) and has been discussed in prior studies of mactrids (Ambrose et al. 1980, Sasaki et al. 2004). This emphasis is pertinent to the study of shallow shelf systems in high latitudes where direct measures of water column chlorophyll are limited by field access in harsh and remote environments, and where these measures are used to drive algorithms relating field data to observations of ocean color from satellite telemetry. Direct measures are limited by temporal and spatial access, while satellite data integrate over a limited depth from the ocean surface that may or may not extend to the benthos. An argument can be proffered that both water column chlorophyll and satellite derived measures of available food to the benthos may provide an underestimate of the true measure of food available over considerable swaths of shallow continental shelves. In turn this raises the question as to the productivity of food chains underpinned in part by benthic production. Is this possible underestimate significant and is it changing in high latitude systems where seasonal ice cover is decreasing? We need more data. 


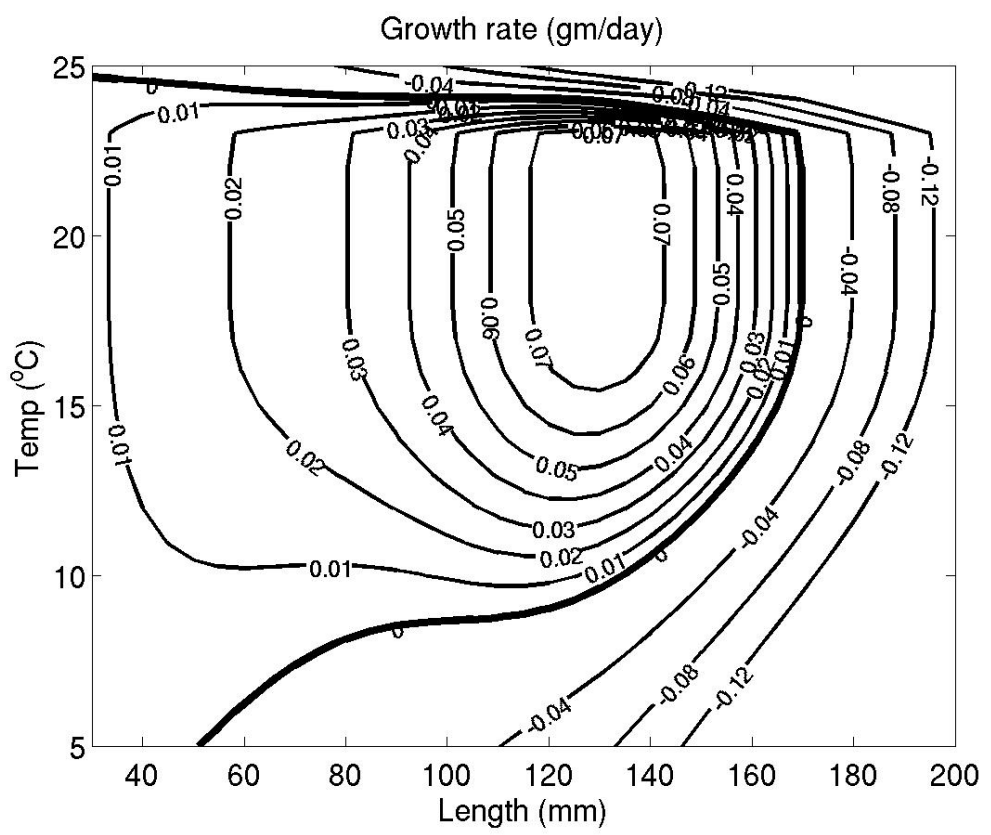

Figure 2. Scope for growth (SFG) of the surfclam Spisula solidissima in relation to temperature at $1 \mathrm{mg}$ per $\mathrm{L}$ food. Maximum SFG occurs between 15 and $23^{\circ} \mathrm{C}$ and 120 and $140 \mathrm{~mm}$ length. The contour of zero SFG, given by the thick line, tracks with increasing length as temperature increases to approximately $18^{\circ} \mathrm{C}$, remains stable until $23^{\circ} \mathrm{C}$, then decreases rapidly to $<40 \mathrm{~mm}$ at $25^{\circ} \mathrm{C}$.

\section{Mactrids as environmental recorders in high latitude continental shelf systems}

Whereas bivalves are familiarly used as sentinel organisms to monitor coastal ecosystem health (Green et al. 1983, O'Connor 1996, Kim et al. 2008), their use in deeper water to monitor climate change is largely unconsidered, though their physiology is appropriately sensitive to variations in temperature and food supply (e.g., MacDonald and Thompson 1985, Roy et al. 2001, Kim and Powell 2004). Ambrose et al. (2006) and Carroll et al. (2009) have made a strong argument that long-lived sessile bivalve molluscs can be employed as location-specific environmental barometers for high latitude systems. Can we use this environmental sensing to provide time-integrated proxies for primary production? We proffer a positive opinion. With the arctic shelf as a target region, can we choose a sentinel species or suite of species that allow reconstruc- 
tion of recent changes in relation to climate change? Sentinel species must have a broad distribution in the target region, be long-lived, have a sufficiently well understood physiology and growth dynamics that de novo efforts in bioenergetic modeling is not required, and can be collected with relative ease. Mactrid clams emerge as candidates for Northern Hemisphere continental shelf ecosystems in general, and the pink neck clam, Mactromeris polynyma (Stimpson, 1860) (synonym Spisula polynyma, see Turgeon et al. 1988, Catalogue of Life 2007), in particular for the shallow waters of the arctic continental shelf.

Mactrids are among the largest bivalves that do not host symbiotic chemoautotrophs or photoautotrophs. They are both long-lived, often are biomass dominants, and have regionally extensive ranges. They are infaunal, are found in sand and sand-mud sediment mixtures, but generally avoid regions subject to regular hypoxia, which may produce confounding growth signatures. The growth form is usually isodiametric. Vermeij (1991) argues that their distribution across three oceans results from an early Pliocene expansion from the Pacific to the Arctic and North Atlantic Oceans as part of the trans-arctic interchange. Although other large and long-lived bivalves occur throughout the world (e.g., Butler and Keough 1981, Wisshak et al. 2009, Titschack et al. 2010), few other than Arctica islandica (Schone et al. 2005, Ridgeway and Richardson 2011) have these favorable traits. The genus Spisula is represented in the western North Atlantic by the benthic dominant Spisula solidissima (Dillwyn, 1817) on the middle Atlantic shelf from Cape Hatteras to a northern limit on Georges Bank and the southern Gulf of Maine (Merrill and Ropes 1969, Franz and Merrill 1980). Spisula solidissima supports a major fishery, is well documented with respect to population biology and growth dynamics (Jacobsen and Weinberg 2006, NEFSC 2010), and is a major indicator of species response to ongoing climate change over its distribution (Weinberg 2005, McCay et al. 2011). To the south of Spisula solidissima is the limited shallow-water distribution of Spisula solidissima similis (Say, 1822) [also described as Spisula raveneli (Conrad, 1831)]', a species limited in terminal size, arguably driven by seasonal higher water temperatures and the allometric discord between energy budget functions as described earlier. In the southern New England to northern rim of the Georges Bank, the dominant

1 Museum type specimens are lacking in the National Museum of Natural History collection at the Smithsonian Institution (Dr. Michael Vecchione, National Systematics Laboratory, pers. comm.), and the Academy of Natural Sciences of Philadelphia (Jacobsen and Old 1966). Abbott (1974) suggests that S. raveneli may be a synonym of S. s. similis; however, Jacobsen and Old (1966) and Porter and Schwartz (1981) suggest the use of $S$. raveneli to be more appropriate and that the distinction be at the species, rather than subspecies level. Neither Theroux and Wigley (1983), nor Turgeon et al. (1988) recognize $S$. raveneli or S. s. similis. Abbott (1974) suggests that S. s. similis is found from Cape Cod to Texas including both sides of the Florida peninsula-a range that would warrant inclusion in Theroux and Wigley (1983). Descriptions of either S. s. similis or S. raveneli south of Cape Hatteras are limited (Kanti et al. 1993, Walker and Heffernan 1993). Growth and age data indicate more rapid growth in the southern species with a smaller maximum size and age (76 $\mathrm{mm}$ and 4 years in Georgia, $135 \mathrm{~mm}$ and 5.5 years in Florida) than S. solidissima (up to $226 \mathrm{~mm}$ and 37 years). 
mactrid grades from Spisula solidissima to Mactromeris polynyma with the latter continuing along the northeastern Atlantic shoreline through the Canadian Maritimes and Labrador Strait (also known as the Strait of Belle Isle) to a pan-arctic distribution with a western component extending from the Juan de Fuca Strait to Point Barrow, Alaska, and Sakhalin Island, Russia (Chamberlin and Sterns 1963, DFO 2007). For completeness, the continuum of species progresses west with Spisula sachalinensis into the Sea of Japan (Golikov and Scarlato 1970), a species for which Sasaki $(1981,1982)$ provides both a Von Bertalanffy growth descriptor and size versus fecundity estimator. To the east the northern European shelf from the Iberian Peninsula to Norway is habitat for Spisula solida (Linnaeus, 1758) (Conchological Society of Great Britain and Ireland 2011). The smaller Spisula subtruncata (da Costa, 1778) $(50 \mathrm{~mm}$ versus $26 \mathrm{~mm}$ maximum length) occupies the corresponding shallow subtidal depths, in addition to extending into the northwestern Mediterranean Sea, where Fraschetti et al. (1997) address population level dynamics in the Ligurian Sea. Population structure and dynamics of Spisula solida have been examined in support of fishery management and aquaculture (Fahey et al. 2003, Dolbeth et al. 2006, Joaquim et al. 2008a). The resource has arguably been overexploited in part of the range (Gaspar et al. 2003, Joaquim et al. 2008b). Reuda and Smaal (2002, 2004) provide data on the physiological energetics of individual Spisula subtruncata.

A rich quantitative literature on the life history, population dynamics, and bioenergetics exists for the genus Spisula from three continental margins. Indeed, in the manner that Ambrose et al. (2006) and Carroll et al. (2009) reported the record of climate change in the shells of the Greenland smooth cockle, Serripes groenlandicus, in the Barents Sea there are also records of response of Spisula solidissima to climate change in the Mid-Atlantic Bight. Weinberg (2005), based on long-term stock assessment survey data, notes a bathymetric shift in distribution in response to warmer ocean temperature wherein the southern range limit is moving north while simultaneously moving to deeper water. Picariello (2006) noted changes in growth rate within a generational time frame at locations in this southern transitioning zone. In combination with a current bioenergetics model of Munroe et al. (2013), the proposal to employ the genus Spisula as a continental shelf sentinel species as describe earlier is supported. What is the status of knowledge for Mactromeris polynyma and can it be included in this effort?

Mactromeris polynyma has supported a major fishery in the Maritimes since 1986; a comprehensive assessment report describing population biology and growth dynamics is available (DFO 2007, see also Hargrave et al. 2004). The oldest individual collected was 61 years old and the largest $157 \mathrm{~mm}$ maximum dimension (length, anteriorposterior parallel to the hinge) from a 2004 survey of the Banquereau Bank in the Scotia-Fundy Region. Natural mortality was estimated at 
$0.08 \mathrm{yr}^{-1}$ for this population. Hughes and Bourne (1981) describe a 1977 and 1978 subtidal assessment of Mactromeris polynyma in the Bering Sea with a projected exploitable biomass of 329,000 $\pm 52,000$ t. A maximum cohort biomass occurs between 9.4 and 13.0 years of age. Growth is slow with a Von Bertalanffy $K=0.135 \mathrm{yr}^{-1}$ and a conservative mortality, $M=0.19 \mathrm{yr}^{-1}$. A draft fishery management plan for the Alaska resource was developed as early as 1979 (NPFMC 1979). Maximum age for the Alaska population is estimated at 25 years (DFO 2007). This disparity in maximum age was confirmed by Cassista and Hart $(2005,2007)$ who found that the Alaska and Atlantic populations of Mactromeris polynyma were significantly differentiated using microsatellite markers. The Alaska population had greater allelic richness supporting the previously described arguments of Vermeij (1991) that mactrids originated in the North Pacific. Cassista and Hart (2007), noting regular recruitment and little genetic diversity among year classes in both Alaska and Atlantic populations, suggest a "spatially broad and temporally persistent genetic homogeneity of these bivalves." Paul and Feder (1976) report that Alaska Mactromeris polynyma also occur locally in dense intertidal aggregations. It is a common food for bearded seals (Erignathus barbatus) and walrus (Odobenus rosmarus divergens) (Fay et al. 1977, NPFMC 1979, Ray et al. 2006). Again, stability in recruitment and genetics of a sentinel organism is desirable; it insures that observed changes in growth are reflective of the local environment.

\section{Extending the reference time frame with archaeology: is this an option?}

Long-lived species provide commensurate time frames of information when collected live. Field collected shells from dead specimens can extend the time frame backward with chronology being provided by carbon isotopes. Can additional information be garnered through archaeological studies of indigenous communities with their traditions of hunting and fishing? Shallow seas provide convenient harvest grounds for native populations. Bivalve shells provide records of harvest and degrade very slowly in both trash pits and shell middens. For example, Harding et al. (2008a, 2010) used oyster shells recovered from an archaeological site at Jamestown, Virginia, to reconstruct riverine temperature and salinity during the "starving times" of early colonial settlers. The important point is that the sclerochronological record is retained in such material (Rollins et al. 1990). Clam shells, together with bison scapula, were favored tools for mounding earth at burial sites in North American pre-Columbian cultures of the Early and Middle Woodland Periods (approximately 1000 BC-500 AD), with extensive records of clam shell tools from Nova Scotia to the Gulf of Mexico. Trash pits and middens are among the targets of archaeologi- 
cal excavation in Alaska with time markers varying from stone, bone, and ivory tools to fiber tempered pottery (summary at http://www.nps. gov/akso/akarc/arctic.htm). The option for abundant clam shell in such locations is probably limited because of seasonal access to intertidal resources in combination with the long appreciated threat of paralytic shellfish poisoning ( $\mathrm{R}$. RaLonde, University of Alaska Fairbanks, pers. comm.); however, the recent discovery of "clam gardens" (Clark 2010) may provide an opportunity to examine butter clam (Saxidomus giganteus) shells from dated archaeological settings.

\section{Where to now?}

Climate change is upon us and is generating substantial reorganizations of shelf communities in temperate and boreal regions (e.g., Southward et al. 1995, Sagarin et al. 1999, Lucey and Nye 2010). Today, as in the past (e.g., Haveles and Ivany 2010), large bivalves are an indicator of robust primary production. Declines in food supply (e.g., Boyce et al. 2010; see also Powell et al. 1995, Manzano-Sarabia et al. 2008) can be expected to seriously affect the larger filter feeders that require high food supply to overcome the differential scaling of ingestion and respiration (e.g., Kim and Powell 2004; see also Marzec et al. 2010). Sentinel organisms are needed wherever routine survey data are inadequate to document change. Large bivalves, slaves to their physiology, are particularly sensitive to variations in temperature and food supply. Ranges are less stable (Roy et al. 2001) as a consequence. Life spans are long. Maximum shell size is a reliable indicator of the most optimal routinely experienced conditions. Condition is an early indicator of suboptimal conditions (Marzec et al. 2010, Kim and Powell 2004). These characteristics make large bivalves obvious choices as sentinels of environmental change.

Munroe et al. (2013) provide the modeling structure to relate observed field data to food requirements, and hence primary production available to the food web supporting capture fisheries. A substantial base of information already exists; the challenge going forward is to create a sampling program to provide additional information to allow a clam "proxy" of productivity (water column plus benthic) across the geographic range targeted by the collected contributions in this volume. Discussion with and guidance from ongoing arctic fisheries and benthic programs would be productive. But why stop there? The temperate through boreal continental shelves of the Northern Hemisphere are all experiencing climate driven migration of species distributions. In this contribution we have argued that mactrids are suitable sentinels or "canaries in the coal mine" to monitor this process and provide the basis for future projections. If there is general agreement on the utility of this approach among fishery biologists and benthic ecologists, then an argument exists to extend examination to the shelf species 
of both the northwestern Pacific Rim and the northwestern European shelf. A holistic approach extending both geographically in footprint and methodologically from the benthos to satellite telemetry provides a structure to examine climate change impacts on shelf communities at the hemisphere level. We should embrace the possibility.

\section{Acknowledgments}

This work was supported by National Science Foundation Award GEO0909484 to all authors, and a Plumeri Award for Faculty Excellence at the College of William and Mary to RM. RM is indebted to Ray RaLonde, University of Alaska Fairbanks, for generous sharing of local knowledge of clam fisheries in Alaska, and to an anonymous reviewer for constructive comments. This is contribution number 3328 from the Virginia Institute of Marine Science.

\section{References}

Abbott, R.T. 1974. American seashells. $2^{\text {nd }}$ edn. Van Nostrand Reinhold, New York. 663 pp.

Ambrose, W.G., D.S. Jones, and I. Thompson. 1980. Distance from shore and growth rate of the suspension feeding bivalve, Spisula solidissima. Proceedings of the National Shellfisheries Association 70:207-215.

Ambrose, W.G., M.L. Carroll, M. Greenacre, S.R. Thorrold, and K.W. McMahon. 2006. Variation in Serripes groenlandicus (Bivalvia) growth in a Norwegian high-Arctic fjord: Evidence for local- and large-scale climatic forcing. Global Change Biology 12:1595-1607. http://dx.doi.org/10.1111/j.1365-2486.2006.01181.x

Bayne, B.L. 1976. Marine mussels, their ecology and physiology. Cambridge University Press, Cambridge, UK. 506 pp.

Bernard, F.R. 1983. Catalogue of the living Bivalvia of the eastern Pacific Ocean: Bering Strait to Cape Horn. Can. Spec. Publ. Fish. Aquat. Sci. 61. $102 \mathrm{pp}$.

Boyce, D.G., M.R. Lewis, and B. Worm. 2010. Global phytoplankton decline over the past century. Nature 466:591-596. http://dx.doi.org/10.1038/nature09268

Brown, J.H., J.F. Gillooly, A.P. Allen, V.M. Savage, and G.B. West. 2004. Toward a metabolic theory of ecology. Ecology 85:1771-1789. http://dx.doi.org/10.1890/03-9000

Burek, K.A., F.M.D. Gulland, and T.M. O'Hara. 2008. Effects of climate change on arctic marine mammal health. Ecol. Appl. 18:S126-S134. http://dx.doi.org/10.1890/06-0553.1

Butler, A.J., and M.J. Keough. 1981. Distribution of Pinna bicolor Gmelin (Mollusca: Bivalvia) in South Australia, with observations on recruitment. Transactions of the Royal Society of South Australia 105:29-39. 
Calow, P. 1977. Conversion efficiencies in heterotrophic organisms. Biological Reviews of the Cambridge Philosophical Society 52:385-409. http://dx.doi.org/10.1111/j.1469-185X.1977.tb00840.x

Carroll, M.L., B.J. Johnson, G.A. Henkes, K.W. McMahon, A. Voronkov, W.G. Ambrose Jr., and S.G. Deisenko. 2009. Bivalves as indicators of environmental variation and potential anthropogenic impacts in the southern Barents Sea. Mar. Pollut. Bull. 59:193-206. http://dx.doi.org/10.1016/j.marpolbul.2009.02.022

Cassista, M.C., and M.W. Hart. 2005. Isolation and characterization of new microsatellite markers in the surfclam Mactromeris polynyma. Mol. Ecol. Notes 5:218-219. http://dx.doi.org/10.1111/j.1471-8286.2005.00881.x

Cassista, M.C., and M.W. Hart. 2007. Spatial and temporal genetic homogeneity in the arctic surfclam (Mactromeris polynyma). Mar. Biol. 152:569-579. http://dx.doi.org/10.1007/s00227-007-0711-3

Catalogue of Life. 2007. Annual Checklist: The Integrated Taxonomic Information System. www.catalogueoflife.org/annual-checklist/2011/info/ cite

Chamberlin, J.L., and F. Sterns. 1963. A geographic study of the clam, Spisula polynyma (Stimpson). American Geographic Society, Serial Atlas Marine Environment, Folio 3:1-12.

Chute, A.S., S.C. Wainright, and D.R. Hart. 2012. Timing of shell ring formation and patterns of shell growth in the sea scallop Placopecten magellanicus based on stable oxygen isotopes. J. Shellfish Res. 31:649-662. http://dx.doi.org/10.2983/035.031.0308

Clark, T.N. 2010. Constructed habitats: Kwakwaka'wakw Clam Gardens and the production of a resource landscape. Paper presented at the 2010 International Congress of Archaeozoology Conference, Paris, France. https://sites.google.com/site/tcrntnc/clam-gardens-of-the-northwest-coast

Conchological Society of Great Britain and Ireland. 2011. http://www.conchsoc.org/spAccount/spisula-solida

Crenshaw, M.A., and J.M. Neff. 1969. Decalcification at the mantle-shell interface in molluscs. Am. Zool. 9:881-885.

DFO. 2007. Assessment of the ocean quahog (Arctica islandica) stocks on Sable Bank and St. Mary's Bay, and the arctic surfclam (Mactromeris polynyma) stock on Banquereau. Department of Fisheries and Oceans, Canadian Science Advisory Secretariat Science Advisory Report. 2007/034. http://www.dfo-mpo.gc.ca/csas/Csas/status/2007/SAR-AS2007_034_E.pdf

Dolbeth, M., I. Viegas, F. Martinho, J.C. Marques, and M.A. Pardal. 2006. Population structure and species dynamics of Spisula solida, Diogenes pugilator and Branchiostoma lanceolatum along a temporal-spatial gradient in the south coast of Portugal. Estuar. Coastal Shelf Sci. 66:168-176. http://dx.doi.org/10.1016/j.ecss.2005.08.006

Duerden, F. 2004. Translating climate change impacts at the community level. Arctic 57(2):204-212. 
Dunton, K. 1992. Arctic biogeography: The paradox of the marine benthic fauna and flora. Trends Ecol. Evol. 7:183-189. http://dx.doi.org/10.1016/0169-5347(92)90070-R

Fahey, E., J. Carroll, M. O'Toole, and J. Hickey. 2003. A preliminary account of fisheries for the surf clam Spisula solida (L.) (Mactracea) in Ireland. Fisheries Bulletin 21. The Marine Institute, Marine Fisheries Services Division, Abbotstown, Dublin, Eire. 31 pp.

Fay, H.F., H.M. Feder, and S.W. Stoker. 1977. An estimation of the impact of the Pacific walrus population on its food resources in the Bering Sea. Final Report US Marine Mammal Commission No. PB-275-505. National Technical Information Service, Springfield, VA.

Flye-Sainte-Marie, J., F. Jean, C. Paillard, S. Ford, E. Powell, E. Hofmann, and J. Klinck. 2007. Ecophysiological dynamic model of individual growth of Ruditapes philippinarum. Aquaculture 266:130-143. http://dx.doi.org/10.1016/j.aquaculture.2007.02.017

Franz, D., and A.S. Merrill. 1980. Molluscan distribution patterns on the continental shelf of the Middle Atlantic Bight (Northwest Atlantic). Malacologia 19:209-225.

Fraschetti, S., A. Covazzi, M. Chiantore, and G. Albertelli. 1997. Life history traits of the bivalve Spisula subtruncata (da Costa) in the Ligurian Sea (North-West Mediterranean): The contribution of newly settled juveniles. Sci. Mar. 61:25-32.

Fry, B. 1988. Food web structure of Georges Bank from Stable C, N, and $\mathrm{S}$ isotopic compositions. Limnol. Oceanogr. 33:1182-1190. http://dx.doi.org/10.4319/lo.1988.33.5.1182

Gaspar, M.B., F. Leitão, M.N. Santos, L. Chícharo, M.D. Dias, A. Chícharo, and C.C. Monteiro. 2003. A comparison of direct macrofaunal mortality using three types of clam dredges. ICES J. Mar. Sci. 60:733-742. http://dx.doi.org/10.1016/S1054-3139(03)00023-7

Golikov, A.N., and O.A. Scarlato. 1970. Abundance, dynamics and production properties of populations of edible bivalves Mizuhopecten yessoensis and Spisula sachalinensis related to the problem of organization of controllable submarine farms at the western shores of the Sea of Japan. Helgoländer Wissenschaftliche Meeresun. 20:498-513. http://dx.doi.org/10.1007/BF01609925

Grebmeier, J.M., L.W. Cooper, H.M. Feder, and B.I. Sirenko. 2006a. Ecosystem dynamics of the Pacific-influenced northern Bering and Chukchi seas in the Amerasian Arctic. Prog. Oceanogr. 71:331-361. http://dx.doi.org/10.1016/j.pocean.2006.10.001

Grebmeier, J.M., J.E. Overland, S.E. Moore, E.V. Farley, E.C. Carmack, et al. 2006b. A major ecosystem shift observed in the northern Bering Sea. Science 311:1461-1464. http://dx.doi.org/10.1126/science.1121365

Green, R.H., S.M. Singh, and R.C. Bailey. 1983. Bivalve molluscs as response systems for modelling spatial and temporal environmental patterns. Sci. Total Environ. 46:147-169. http://dx.doi.org/10.1016/0048-9697(85)90291-8 
Harding, J.M., R. Mann, and M. Southworth. 2008a. Shell length at age relationships in James River oysters (Crassostrea virginica) collected four centuries apart. J. Shellfish Res. 27:1109-1115. http://dx.doi.org/10.2983/0730-8000-27.5.1109

Harding, J.M., S.E. King, E.N. Powell, and R. Mann. 2008b. Decadal trends in age structure and recruitment patterns of ocean quahogs Arctica islandica from the Mid-Atlantic Bight in relation to water temperature. J. Shellfish Res. 27:667690. http://dx.doi.org/10.2983/0730-8000(2008)27[667:DTIASA]2.0.CO;2

Harding, J.M., H.J. Spero, R. Mann, G. Herbert, and J. Sliko. 2010. Reconstructing early $17^{\text {th }}$ century estuarine drought conditions from Jamestown oysters. P. Natl. Acad. Sci. USA 107(23):10549-10554. http://dx.doi.org/10.1073/pnas.1001052107

Hargrave, B.T., V.A. Kostylev, and C.M. Hawkins. 2004. Benthic epifauna assemblages, biomass and respiration in The Gully region on the Scotian Shelf, NW Atlantic Ocean. Mar. Ecol. Prog. Ser. 270:55-70. http://dx.doi.org/10.3354/meps270055

Haveles, A.W., and L.C. Ivany. 2010. Rapid growth explains large size of mollusks in the Eocene Gosport Sand, United States Gulf Coast. Palaios 25:550564. http://dx.doi.org/10.2110/palo.2009.p09-148r

Hobson, K.A., W.G. Ambrose, and P.E. Renaud. 1995. Sources of primary production, benthic-pelagic coupling, and trophic relationships within the Northeast Water Polynya: Insights from delta $13 \mathrm{C}$ and delta $15 \mathrm{~N}$ analysis. Mar. Ecol. Prog. Ser. 128:1-10. http://dx.doi.org/10.3354/meps128001

Hofmann E.E., E.N. Powell, J.M. Klinck, and G. Saunders. 1995. Modeling diseased oyster populations I. Modeling Perkinsus marinus infections in oysters. J. Shellfish Res. 14:121-151.

Hofmann, E.E., E.N. Powell, J.M. Klinck, and E.A. Wilson. 1992. Modeling oyster populations III. Critical feeding periods, growth and reproduction. J. Shellfish Res. 11:399-416.

Hofmann, E.E., E.N. Powell, J.M. Klinck, S. Boyles, and M.S. Ellis. 1994. Modeling oyster populations II. Adult size and reproductive effort. J. Shellfish Res. 13:165-182.

Hofmann, E.E., J.M. Klink, J.N. Kraueter, E.N. Powell, R. Grizzle, S. Buckner, and V.M. Bricelj. 2006. Population dynamics model of the hard clam, Mercenaria mercenaria: Development of the age- and lengthfrequency structure of the population. J. Shellfish Res. 25:417-444. http://dx.doi.org/10.2983/0730-8000(2006)25[417:APDMOT]2.0.CO;2

Hofmann, E., J.N. Druon, K. Fennel, M. Friedrichs, D. Haidvogel, C. Lee, A. Mannino, C. McClain, R. Najjar, J. O’Reilly, D. Pollard, M. Previdi, S. Seitzinger, J. Siewert, S. Signarini, and J. Wilkin. 2008. Eastern US continental shelf carbon budget integrating models, data assimilation, and analysis. Oceanography 21:86-104. http://dx.doi.org/10.5670/oceanog.2008.70

Hughes, S.E., and N. Bourne. 1981. Stock assessment and life history of a newly discovered Alaska surf clam (Spisula polynyma) resource in the southeastern Bering Sea. Can. J. Fish. Aquat. Sci. 38:1173-1181. http://dx.doi.org/10.1139/f81-158 
Hunt Jr., G.L., P. Stabeno, G. Walters, E. Sinclair, R.D. Brodeur, et al. 2002. Climate change and control of the southeastern Bering Sea pelagic ecosystem. DeepSea Res. Pt. II 49:5821-5853. http://dx.doi.org/10.1016/S0967-0645(02)00321-1

Hyun, K.H., I.C. Pang, J.M. Klinck, K.S. Choi, J.B. Lee, E.N. Powell, E.E. Hofmann, and E.A. Bochenek. 2001. The effect of food composition on Pacific oyster Crassostrea gigas (Thunberg) growth in Korea: A modeling study. Aquaculture 199:41-62. http://dx.doi.org/10.1016/S0044-8486(01)00509-9

IPCC. 2007. Intergovernmental Panel on Climate Change. Fourth Assessment Report. IPCC Secretariat, Geneva, Switzerland.

Jacobsen, L.D., and J.R. Weinberg. 2006. Atlantic surf clam. http://www.nefsc. noaa.gov/sos/spsyn/iv/surfclam/archives/34_AtlanticSurfclam_2006.pdf

Jacobsen, M.K., and W.E. Old Jr. 1966. On the identity of Spisula similis. American Malacological Union Inc. Annual Report 1966, pp. 30-31.

Joaquim, S., M.B. Gaspar, D. Matias, R. Ben-Hamadou, and W.S. Arnold. 2008a. ICES J. Mar. Sci. 65:60-64. http://dx.doi.org/10.1093/icesjms/fsm167

Joaquim, S., D. Matias, B. Lopes, W.S. Arnold, and M.B. Gaspar. 2008b. The reproductive cycle of white clam Spisula solida (L.) (Mollusca: Bivalvia): Implications for aquaculture and wild stock management. Aquaculture 281:43-48. http://dx.doi.org/10.1016/j.aquaculture.2008.05.018

Jones, D.S., and I.R. Quitmeyer. 1996. Marking time with bivalve shells: Oxygen isotopes and season of annual increment formation. Palaios 11:340-346. http://dx.doi.org/10.2307/3515244

Jones, D.S., M.A. Arthur, and D.J. Allard. 1989. Sclerochronological records of temperature and growth from shells of Mercenaria mercenaria from Narragansett Bay, Rhode Island. Mar. Biol. 102:225-234. http://dx.doi.org/10.1007/BF00428284

Jones, D.S., D.F. Williams, and M.A. Arthur. 1983. Growth history and ecology of the Atlantic surf clam, Spisula solidissima (Dillwyn), as revealed by stable isotopes and annual shell increments. J. Exp. Mar. Biol. Ecol. 73:225242. http://dx.doi.org/10.1016/0022-0981(83)90049-7

Kanti, A., P.B. Heffernan, and R.L. Walker. 1993. Gametogenic cycle of the southern surf clam, Spisula solidissima similis (Say 1822), from St. Catherines Sound, Georgia. J. Shellfish Res. 12(1):255-261.

Kilada, R.W., S.E. Campana, and D. Roddick. 2009. Growth and sexual maturity of the northern propeller clam (Cyrtodaria siliqua) in eastern Canada, with bomb radiocarbon age validation. Mar. Biol. 156:1029-1037. http://dx.doi.org/10.1007/s00227-009-1146-9

Kilada, R.W., D. Roddick, and K. Mombourquette. 2007. Age determination, validation, growth and minimum size of sexual maturity of the Greenland smooth cockle (Serripes groenlandicus, Bruguiere, 1789) in eastern Canada. J. Shellfish Res. 26:443-450. http://dx.doi.org/10.2983/0730-8000(2007)26[443:ADVGAM]2.0.CO;2

Kim, Y., and E.N. Powell. 2004. Surfclam histopathology survey along the Delmarva mortality line. J. Shellfish Res. 23:429-441. 
Kim, Y., E.N. Powell, T.L. Wade, and B.J. Presley. 2008. Relationship of parasites and pathologies to contaminant body burden in sentinel bivalves: NOAA Status and Trends 'Mussel Watch' Program. Mar. Environ. Res. 65:101-127. http://dx.doi.org/10.1016/j.marenvres.2007.09.003

Kirby, M.X., T.S. Soniat, and H.J. Spero. 1998. Stable isotope sclerochronology of Pleistocene and Recent oyster shells (Crassostrea virginica). Palaios 13:560-569. http://dx.doi.org/10.2307/3515347

Kobayashi, M., E.E. Hofmann, E.N. Powell, J.M. Klinck, and K. Kusaka. 1997. A population dynamics model for the Japanese oyster, Crassostrea gigas. Aquaculture 149(3-4):285-321. http://dx.doi.org/10.1016/S0044-8486(96)01456-1

Krupnik, I., and D. Jolly (eds.) 2002. The earth is faster now: Indigenous observations of arctic environmental change. Frontiers in Polar Social Science. Arctic Research Consortium of the United States, Fairbanks. 383 pp.

Lika, K., and R.M. Nisbe. 2000. A dynamic energy budget model based on partitioning of net production. J. Math. Biol. 41:361-386. http://dx.doi.org/10.1007/s002850000049

Lucey, S.M., and J.A. Nye. 2010. Shifting species assemblages in the northeast US continental shelf large marine ecosystem. Mar. Ecol. Prog. Ser. 415:2333. http://dx.doi.org/10.3354/meps08743

MacDonald, B.A., and R.J. Thompson. 1985. Influence of temperature and food availability on the ecological energetics of the giant scallop Placopecten magellanicus. I. Growth rates of shell and somatic tissue. Mar. Ecol. Prog. Ser. 25:279-294. http://dx.doi.org/10.3354/meps025279

Mann, R. 1978. A comparison of morphometric, biochemical and physiological indexes of condition in marine bivalve molluscs. In: J.H. Thorp and J.W. Gibbons (eds.), Energy and environmental stress in aquatic systems. D.O.E. Symposium Series, Conf. 771114, pp. 484-497.

Mann, R., and S.J. Glomb. 1978. The effect of temperature on growth and ammonia excretion of the Manila clam Tapes japonica. Estuar. Coastal Mar. Sci. 6:335-337. http://dx.doi.org/10.1016/0302-3524(78)90021-X

Manzano-Sarabia, M., C.A. Salinas-Zavala, K. Kahru, S.E. Lluch-Cota, and A. González-Becerril. 2008. The impact of the 1997-1999 warm-SST and lowproductivity episode on fisheries in the southwestern Gulf of Mexico. Hydrobiologia 610:257-267. http://dx.doi.org/10.1007/s10750-008-9440-y

Marzec, R.J., Y. Kim, and E.N. Powell. 2010. Geographic trends in weight and condition index of surfclams (Spisula solidissima) in the Mid-Atlantic Bight. J. Shellfish Res. 29:117-128. http://dx.doi.org/10.2983/035.029.0104

McCay, B.J., S. Brandt, and C.F. Creed. 2011. Human dimensions of climate change and fisheries in a coupled system: The Atlantic surfclam case. ICES J. Mar. Sci. 68:1354-1367. http://dx.doi.org/10.1093/icesjms/fsr044

Melia, P., G.A. DeLeo, and M. Gatto. 2004. Density and temperaturedependence of vital rates in the Manila clam Tapes philippinarum: A stochastic demographic model. Mar. Ecol. Prog. Ser. 272:153-164. http://dx.doi.org/10.3354/meps272153 
Merrill, A.S., and J.W. Ropes. 1969. The general distribution of the surf clam and the ocean quahog. Proceedings of the National Shellfish Association 59:40-45.

Munroe, D.M., E.N. Powell, R. Mann, J.M. Klinck, and E.E. Hofmann. 2013. Underestimation of primary productivity on continental shelves: Evidence from maximum size of extant surfclam (Spisula solidissima) populations. Fish. Oceanogr. http://dx.doi.org/10.1111/fog.12016

NEFSC. 2010. 49 $9^{\text {th }}$ Northeast Regional Stock Assessment Workshop (49 $9^{\text {th }}$ SAW) assessment summary report. NOAA Northeast Fisheries Science Center, Reference Document 10-01. 41 pp.

NPFMC. 1979. Alaska surf clam draft fishery management plan, Draft IV. North Pacific Fishery Management Council, Anchorage, AK. 65 pp.

O'Connor, T.P. 1996. Trends in chemical concentrations in mussels and oysters collected along the U.S. coast from 1986 to 1993. Mar. Environ. Res. 41:183-200. http://dx.doi.org/10.1016/0141-1136(95)00011-9

Paul, A.J., and H.M. Feder. 1976. Clam, mussel and oyster resources of Alaska. Alaska Sea Grant and Institute of Marine Science, University of Alaska Fairbanks. 4lpp.

Picariello, A. 2006. The effects of climate change on the population biology of the surf clam, Spisula solidissima, in the Middle Atlantic Bight. M.S. thesis, College of William and Mary, Virginia Institute of Marine Science. 169 pp.

Porter, H.J., and H.J. Schwartz. 1981. Trawl collections of Macoma constricta and Spisula raveneli (Bivalvia: Tellinidae and Mactridae) in vicinity of Cape Fear River, NC and their relationship to periods of environmental stress. Bulletin of the American Malacological Union, pp. 15-19.

Powell, E.N., J.M. Klinck, and E.E. Hofmann. 1996. Modeling diseased oyster populations II. Triggering mechanisms for Perkinsus marinus epizootics. J. Shellfish Res. 15:141-165.

Powell, E.N., E.E. Hofmann, J.M. Klinck, and S.M. Ray. 1992. Modeling oyster populations I. A commentary on filtration rate. Is faster always better? J. Shellfish Res. 11:387-398.

Powell, E.N., E.E. Hofmann, J.M. Klinck, and S.M. Ray. 1994. Modeling oyster populations IV. Rates of mortality, population crashes and management. Fish. Bull. 92:347-373.

Powell, E.N., J.M. Klinck, E.E. Hofmann, and S. Ford. 1997. Varying the timing of oyster transplant: Implications for management from simulation studies. Fish. Oceanogr. 6:213-237. http://dx.doi.org/10.1046/j.1365-2419.1998.00046.x

Powell, E.N., J.M. Klinck, E.E. Hofmann, E.A. Wilson-Ormond, and M.S. Ellis. 1995. Modeling oyster populations 5. Declining phytoplankton stocks and the population dynamics of American oyster (Crassostrea virginica) populations. Fish. Res. 24:199-222. http://dx.doi.org/10.1016/0165-7836(95)00370-P

Ramón, M., and C.A. Richardson. 1992. Age determination and shell growth of Chamelea gallina (Bivalvia: Veneridae) in the western Mediterranean. Mar. Ecol. Prog. Ser. 89:15-23. http://dx.doi.org/10.3354/meps089015 
Ray, G.C., J. McCormick-Ray, P. Berg, and H.E. Epstein. 2006. Pacific walrus: Benthic bioturbator of Beringia. J. Exp. Mar. Biol. Ecol. 330:403-419. http://dx.doi.org/10.1016/j.jembe.2005.12.043

Ren, J.S., and A.H. Ross. 2001. A dynamic energy budget model of the Pacific oyster Crassostrea gigas. Ecol. Model. 142:105-120. http://dx.doi.org/10.1016/S0304-3800(01)00282-4

Ren, J.S., and A.H. Ross. 2005. Environmental influence on mussel growth: A dynamic energy budget model and its application to the green shell mussel Perna canaliculus. Ecol. Model. 189:347-362. http://dx.doi.org/10.1016/j.ecolmodel.2005.04.005

Reuda, J.L., and A.C. Smaal. 2002. Physiological response of Spisula subtruncata (da Costa, 1778) to different seston quality and quantity. Hydrobiologica 475:505-511. http://dx.doi.org/10.1023/A:1020320332350

Reuda, J.L., and A.C. Smaal. 2004. Variation of the physiological energetics of the bivalve Spisula subtruncata (da Costa, 1778) within an annual cycle. J. Exp. Mar. Biol. Ecol. 301:141-157. http://dx.doi.org/10.1016/j.jembe.2003.09.018

Rhoads, D.C., R.A. Lutz (eds.) 1980. Skeletal growth of aquatic organisms. Plenum Press. 750 pp.

Richardson, C.A. 1988. Tidally produced growth bands in the subtidal bivalve Spisula subtruncata (da Costa). J. Molluscan Studies 54(1):71-82. http://dx.doi.org/10.1093/mollus/54.1.71

Richardson, C.A. 2001. Molluscs as archives of environmental change. Oceanogr. Mar. Biol. Ann. Rev. 39:103-164.

Richardson, C.A., C. Saurel, C.M. Barroso, and J. Thain. 2005. Evaluation of the age of the red whelk Neptunea antiqua using statoliths, opercula and element ratios in the shell. J. Exp. Mar. Biol. Ecol. 325:55-64. http://dx.doi.org/10.1016/j.jembe.2005.04.024

Richardson, C.A., M. Peharda, H.A. Kennedy, P. Kennedy, and V. Onofri. 2003. Age, growth rate and season of recruitment of Pinna nobilis (L.) in the Croatian Adriatic determined from Mg:Ca and Sr:Ca shell profiles. J. Exp. Mar. Biol. Ecol. 299:1-16. http://dx.doi.org/10.1016/j.jembe.2003.08.012

Ridgeway, I.D., and C.A. Richardson. 2011. Arctica islandica: The longest lived noncolonial animal known to science. Rev. Fish Biol. Fish. 21:297-310. http://dx.doi.org/10.1007/s11160-010-9171-9

Rollins, H.B., H. Sandweiss, and J.C. Rollins. 1990. Mollusks and coastal archaeology: A review. In: N.P. Lasca and J. Donahue (eds.), Archaeological geology of North America. Geol. Soc. Am. Centennial Special Vol. 4:467-478.

Ropes, J.W. 1984. Procedures for preparing acetate peels and evidence validating the annual periodicity of growth lines formed in the shells of ocean quahogs, Arctica islandica. Mar. Fish. Rev. 46(2):27-35.

Roy, K., D. Jablonski, and J.W. Valentine. 2001. Climate change, species range limits and body size in marine bivalves. Ecol. Lett. 4:366-370. http://dx.doi.org/10.1046/j.1461-0248.2001.00236.x 
Sagarin, R.D., J.P. Barry, S.E. Gilman, and C.H. Baxter. 1999. Climate-related change in an intertidal community over short and long time scales. Ecol. Monogr. 69:465490. http://dx.doi.org/10.1890/0012-9615(1999)069[0465:CRCIAI]2.0.CO;2

Sasaki, K. 1981. Growth of the Sakhalin surf clam, Spisula sachalinensis (Schrenk), in Sendai Bay. Tohoku J. Agricultural Research 32:168-180.

Sasaki, K. 1982. Fecundity of the Sakhalin surf clam, Spisula sachalinensis (Schrenk), in Sendai Bay. Tohoku J. Agricultural Research 33:76-82.

Sasaki, K., A. Sanematsu, Y. Kato, and K. Ito. 2004. Dependence of the surf clam Pseudocardium sachalinense (Bivalvia: Mactridae) on the near-bottom layer for food supply. J. Molluscan Studies 70:207-212. http://dx.doi.org/10.1093/mollus/70.3.207

Schone, B.R., A.D.F. Castro, J. Fiebig, S.D. Houk, W. Oschmann, and I. Kroncke. 2004. Sea surface water temperatures over the period 1884-1983 reconstructed from oxygen isotope ratios of a bivalve mollusk shell (Arctica islandica, southern North Sea). Palaeogeogr. Palaeoecol. 212:215-232.

Schone, B.R., J. Fiebig, M. Pfeiffer, R. Gleb, J. Hickson, A.L.A. Johnson, W. Dreyer, and W. Oschmann. 2005. Climate records from a bivalve Methuselah (Arctica islandica, Mollusca; Iceland). Palaeogeogr. Palaeoecol. 228:130-148. http://dx.doi.org/10.1016/j.palaeo.2005.03.049

Southward, A.J., S.J. Hawkins, and M.T. Burrows. 1995. Seventy years' observations of changes in distribution and abundance of zooplankton and intertidal organisms in the western English Channel in relation to rising sea temperature. J. Theoretical Biology 20:127-155. http://dx.doi.org/10.1016/0306-4565(94)00043-I

Theroux, R.B., and R.L. Wigley. 1983. Distribution and abundance of east coast bivalve mollusks based on specimens in the National Marine Fisheries Service Woods Hole Collections. NOAA Technical Report NMFS SSRF-768. $172 \mathrm{pp}$.

Thorarinsdóttir, G.G., and L.D. Jacobsen. 2005. Fishery biology and biological reference points for the management of ocean quahogs (Arctica islandica) off Iceland. Fish. Res. 75:97-106. http://dx.doi.org/10.1016/j.fishres.2005.04.010

Titschack, J., M. Zuschin, C. Spötl, and C. Baal. 2010. The giant oyster Hyotissa hyotis from the northern Red Sea as a decadal-scale archive for seasonal environmental fluctuations in coral reef habitats. Coral Reefs 29:10611075. http://dx.doi.org/10.1007/s00338-010-0665-7

Turgeon, D.D., A.E. Bogan, E.V. Coan, W.K. Emerson, W.G. Lyons, W.L. Pratt, C.F.E. Roper, A. Scheltema, F.G. Thompson, and J.D. Williams. 1988. Common and scientific names of aquatic invertebrates from the United States and Canada: Mollusks. American Fisheries Society Special Publication 16. 277 pp.

Vermeij, G.J. 1991. Anatomy of an invasion: the trans-arctic interchange. Paleobiology 17:281-307.

Walker, R.L., and P.B. Heffernan. 1993. Age, growth rate, and size of the southern surf clam, Spisula solidissima similis (Say 1822). J. Shellfish Res. 12:157-160. 
Weinberg, J.R. 2005. Bathymetric shift in the distribution of Atlantic surfclams: Response to warmer ocean temperature. ICES J. Mar. Sci. 62:14441453. http://dx.doi.org/10.1016/j.icesjms.2005.04.020

Wilkes, D.A., and M.A. Crenshaw.1979. Formation of a dissolution layer in molluscan shells. Scan. Electron Micros. 2:469-474.

Wisshak, M., M. López Correa, S. Gofas, C. Salas, M. Taviani, J. Jakobsen, and A. Freiwald. 2009. Shell architecture, element composition, and stable isotope signature of the giant deep-sea oyster, Neopycnodonte zibrowii sp. n. from the NE Atlantic. Deep-Sea Res. Pt. I 56:374-407. http://dx.doi.org/10.1016/j.dsr.2008.10.002

Xu, Y., R. Chant, D.L. Gong, R. Castelao, S. Glenn, and O. Schofield. 2011. Seasonal variability of chlorophyll $a$ in the Mid-Atlantic Bight. Cont. Shelf Res. 31:1640-1650. http://dx.doi.org/10.1016/j.csr.2011.05.019 